\title{
SS-017 ビジュアル・ナラティヴの理論と方法
}

2C / 展示室 2

\author{
企画代表者, 話題提供者: やまだようこ（立命館大学） \\ 話題提供者, 司会者: 家島 明彦 (大阪大学) \\ 話题提供者: 木戸 彩恵 (関西大学) \\ 話題提供者: 滑田 明暢 (滋賀大学) \\ 話題提供者: 浦田悠 (大阪大学)
}

従来のナラティヴ・アプローチでは, 相互行為（インタラクション）の媒体として「狭義の言語」に よる語りが重視されてきた。それに対してビジュアル・ナラティヴは, イメージ（画像・映像）を伴う 視覚的ナラティヴに焦点をある。ナラティヴを視覚的イメージにまで広げると,「ナラティヴ」の定義や 分析方法も変革せざるをえない。特に西欧の言語では主体（主語）や時間系列を重視してきた。しかし， 視覚的イメージでは, 絵巻物や曼荼羅のように複数の自己や異なる時間を同じ空間に共存させることが できる。また，時間は「はじまり」から「㧍り」へと前進的に流れるとは限らない。私たちが現在生 きている世界は, 現実の世界とイメージの世界が不可分に重なるパラレル・ワールドでもあり, 未来の イメージが現実をつくっていくという見方もできる。ビジュアル・ナラティヴによって, 最先端の新し いナラティヴ世界を切り開く理論と方法論を提案する。

第1日 9 月20日(水) $14: 30 \sim 16: 10$

4 C / 中会議室 1

\section{SS-018 教育現場でもまばたきでコミュニケーションしよう！}

\author{
企画代表者, 指定討論者：田中裕 (川村学園女子大学) \\ 企画者, 司会者: 福田 恭介 (福岡県立大学) \\ 話题提供者: 野村 亮太 (東京大学) \\ 話題提供者 : 宮地弘一郎\# (信州大学) \\ 指定討論者: 山田冨美雄 (関西福祉科学大学) \\ 司会者 : 大森 慈子 (仁愛大学)
}

近年脳内機構との関連がより明確化しつつある瞬目は, 実験室内での測定だけでなくフィールド研究 での利用も増えてきている。本シンポジウムでは, 教育現場に掞けるコミュニケーション支援に関連し た瞬目に関する研究 2 つを話題として提供していただく。小学校の授業場面における生徒と教員の瞬目 同期に注目した研究 (野村), および特別支援教育場面における重度重複障害児への援助指標としての瞬 目に注目した研究 (宮地), である。これらの 2 つの研究は, 瞬目指標から対象者の心理的変化を評価す るだけはなく, 脳内視覚情報処理活動も考慮した検討を行っている。他の脳内活動を反映する指標より 容易に測定できる瞬目の特性を活かした研究といえる。今回の話題を踏まえて, 本シンポジウムを多様 な可能性を持つ瞬目研究の検証, およびそこに潜む問題点についての議論, を重ねる場としたい。本シ ンポジウムは「まばたき研究会」の主催による。 